\title{
Plasma islet amyloid polypeptide (Amylin) levels and their responses to oral glucose in Type 2 (non-insulin-dependent) diabetic patients
}

\author{
T. Sanke, T. Hanabusa, Y. Nakano, C. Oki, K. Okai, S. Nishimura, M. Kondo and K. Nanjo \\ The First Department of Medicine, Wakayama University of Medical Science, Wakayama, Japan
}

\begin{abstract}
Summary. Fasting plasma islet amyloid polypeptide concentrations and their responses to an oral glucose load were determined in non-diabetic control subjects and patients with abnormal glucose tolerance in relation to the responses of insulin or C-peptide. Plasma islet amyloid polypeptide was measured by radioimmunoassay. In the non-diabetic control subjects, fasting plasma islet amyloid polypeptide was $6.4 \pm 0.5 \mathrm{fmol} / \mathrm{ml}$ (mean $\pm \mathrm{SEM}$ ) and was about $1 / 7$ less in molar basis than in insulin. The fasting islet amyloid polypeptide level rose in obese patients and fell in patients with Type 1 (insulin-dependent) diabetes mellitus. In non-obese patients with impaired glucose tolerance and Type 2 (non-insulin-dependent) diabetic patients without insulin therapy, the level was equal to that of the control subjects, but a low concentration of islet amyloid polypeptide relative to insulin
\end{abstract}

or C-peptide was observed in the non-obese Type 2 diabetic group. The patterns of plasma islet amyloid polypeptide responses after oral glucose were similar to those of insulin or C-peptide. However, compared to non-obese patients, a hyper-response of islet amyloid polypeptide relative to Cpeptide was noted in obese patients who had a hyper-response of insulin relative to $\mathrm{C}$-peptide. This study suggests that basal hypo-secretion of islet amyloid polypeptide relative to insulin exists in non-obese Type 2 diabetes and that circulating islet amyloid polypeptide may act physiologically with insulin to modulate the glucose metabolism.

Key words: Islet amyloid polypeptide, amylin, diabetes mellitus, fasting concentration, oral glucose tolerance test.
Islet amyloid polypeptide (IAPP or Amylin) is a 37 amino acid peptide, which was extracted and characterized from islet amyloid deposits in patients with insulinoma [1] or Type 2 (non-insulin-dependent) diabetes [2]. Recent immunohistochemical studies and the characterization of IAPP cDNA suggest that IAPP is a normal islet hormone and is co-secreted with insulin from islet Beta cells of the pancreas. To establish that IAPP is a hormone, its secretion and physiological action(s) should be elucidated. A recent in vitro study [3] indicates that IAPP is co-released with insulin by glucose and non-glucose stimuli from the Beta cells. With regard to the actions of IAPP, some studies $[4,5]$ using synthesized IAPP amide suggest that IAPP may have insulin antagonistic effects, particularly in muscle tissue. However, interpretation of these results must take into account the peripheral molar ratio of IAPP/insulin as well as the peripheral concentration of IAPP.

In the present study, plasma IAPP concentration and its responses to oral glucose load in non-diabetic subjects and patients with mild glucose intolerance were studied in relation to the responses of insulin and C-peptide to dis- cover the features of the secretions of these Beta cell products in Type 2 diabetes.

\section{Subjects and methods}

\section{Subjects and loading test}

Nineteen non-obese [body mass index $(B M I)<25 \mathrm{~kg} / \mathrm{m}^{2}$ ] normal volunteers [age: $36.7 \pm 3.9$ (mean $\pm \mathrm{SEM}$ ) years, BMI: $\left.20.8 \pm 0.4 \mathrm{~kg} / \mathrm{m}^{2}\right]$ with no family history of diabetes and 79 patients with abnormal glucose tolerance 17 non-obese patients with impaired glucose tolerance (IGT) (age: $54.8 \pm 2.4$ years, BMI: $21.3 \pm 0.6 \mathrm{~kg} / \mathrm{m}^{2}$ ), 32 non-obese Type 2 diabetic patients without insulin therapy (age: $63.2 \pm 2.0$ years, BMI: $22.6 \pm 0.3 \mathrm{~kg} / \mathrm{m}^{2}$ ), seven non-obese Type 2 diabetic patients on insulin therapy (age: $64.0 \pm 4.6$ years, BMI: $20.6 \pm 0.5 \mathrm{~kg} / \mathrm{m}^{2}$ ), eight Type 1 (insulin-dependent) diabetic patients (age: $40.8 \pm 6.8$ years, BMI: $20.2 \pm 0.7 \mathrm{~kg} / \mathrm{m}^{2}$ ), seven obese (BMI $>27 \mathrm{~kg} / \mathrm{m}^{2}$ ) patients with IGT (age: $39.4 \pm 7.3$ years, BMI: $30.4 \pm 0.5 \mathrm{~kg} / \mathrm{m}^{2}$ ), and eight obese Type 2 diabetic patients without insulin therapy (age: $54.8 \pm 10.2$ years, BMI: $\left.\left.32.0 \pm 1.2 \mathrm{~kg} / \mathrm{m}^{2}\right)\right]$ were studied to measure fasting IAPP after overnight fasting. In 43 of these subjects a $75 \mathrm{~g}$ oral glucose tolerance test (OGTT) was performed. $\mathrm{HbA}_{1 \mathrm{c}}$ of the patients studied was less 
Table 1. Fasting plasma levels of Beta cell products and each molar ratio and ratio of each area under the curve above basal (AUC) during oral glucose tolerance test

\begin{tabular}{|c|c|c|c|c|c|c|c|c|c|}
\hline \multirow[b]{2}{*}{ Group } & \multicolumn{6}{|c|}{ Fasting } & \multicolumn{3}{|c|}{ OGTT } \\
\hline & $n$ & $\begin{array}{l}\text { IAPP } \\
(\mathrm{fmol} / \mathrm{ml})\end{array}$ & $\begin{array}{l}\text { insulin } \\
(\mathrm{fmol} / \mathrm{ml})\end{array}$ & $\begin{array}{l}\mathrm{CP} \\
(\mathrm{pmol} / \mathrm{ml})\end{array}$ & $\begin{array}{l}\text { IAPP/insulin } \\
\operatorname{MR}\left(\times 10^{-1}\right)\end{array}$ & $\begin{array}{l}\text { IAPP/CP } \\
\operatorname{MR}\left(\times 10^{-2}\right)\end{array}$ & $n$ & $\begin{array}{l}\mathrm{AUC}_{\mathrm{IN} / \mathrm{P} P} \\
\left(\times 10^{-1}\right)\end{array}$ & $\begin{array}{l}\text { AUC } \mathrm{IAICP} \\
\left(\times 10^{-3}\right)\end{array}$ \\
\hline \multicolumn{10}{|c|}{ Non-obese subjects } \\
\hline IGT & 17 & $6.2 \pm 0.7$ & $37.5 \pm 3.5$ & $0.33 \pm 0.03$ & $2.03 \pm 0.36$ & $2.54 \pm 0.44$ & 12 & $1.37 \pm 0.16^{d}$ & $5.67 \pm 0.47^{\mathrm{e}}$ \\
\hline Type 2-NI & 32 & $6.7 \pm 0.6$ & $61.8 \pm 6.9^{\mathrm{a}}$ & $0.57 \pm 0.07^{\mathrm{c}}$ & $1.23 \pm 0.09^{\mathrm{a}}$ & $1.42 \pm 0.11^{\mathrm{a}}$ & 8 & $1.14 \pm 0.18^{\mathrm{f}}$ & $4.59 \pm 0.64^{\mathrm{g}}$ \\
\hline Type 2-I & 7 & $2.8 \pm 1.1^{\mathrm{c}}$ & & & & & & & \\
\hline \multicolumn{10}{|c|}{ Obese subjects } \\
\hline IGT & 7 & $8.7 \pm 1.0^{\mathrm{a}}$ & $67.4 \pm 13.9^{\mathrm{a}}$ & $0.63 \pm 0.17^{\mathrm{a}}$ & $1.41 \pm 0.21$ & $1.82 \pm 0.37$ & 7 & $2.80 \pm 0.68^{d}$ & $7.83 \pm 1.27^{\mathrm{e}}$ \\
\hline Type 2-NI & 8 & $10.5 \pm 2.6^{\mathrm{a}}$ & $120.1 \pm 36.1^{b}$ & $0.80 \pm 0.17^{\mathrm{b}}$ & $0.98 \pm 0.20^{\mathrm{a}}$ & $1.43 \pm 0.30$ & 5 & $3.06 \pm 0.81^{\mathrm{f}}$ & $8.58 \pm 3.55^{\mathrm{g}}$ \\
\hline
\end{tabular}

IGT: impaired glucose tolerance, Type 2-NI: Type 2 diabetes without insulin therapy, Type 2-I: Type 2 diabetes with insulin therapy, CP: C-peptide, MR: molar ratio, OGTT: oral glucose tolerance test, $\mathrm{AUC}$ : area under the curve above basal during 120 min of OGTT, AUC INCP: AUC of insulin/AUC of C-peptide, $\mathrm{AUC}_{\mathrm{IA} / \mathrm{CP}}$ : AUC of IAPP/AUC of C-peptide, significance of the difference from normal subjects: ${ }^{\mathrm{a}} p<0.05$, ${ }^{b} p<0.01,{ }^{\circ} p<0.001$,

significance of each other: ${ }^{\mathrm{d}} p<0.05,{ }^{\mathrm{e}} p<0.05,{ }^{\mathrm{f}} p<0.05,{ }^{\mathrm{g}}$ not significant

than $8.5 \%$ except in those with Type 1 diabetes. Those who had hepatic or renal dysfunction were excluded.

Peripheral blood samples to measure plasma insulin, C-peptide and IAPP were put into chilled tubes containing $2.5 \mathrm{mg}$ EDTA and 500 Kalliginogenase Inactivator Unit Aprotinin per $\mathrm{ml}$ of blood. The plasma was separated immediately after the completion of the loading test and was stored at $-80^{\circ} \mathrm{C}$.

\section{Extraction of IAPP-like materials in plasma}

Plasma IAPP-like materials were extracted using Sep-Pak C18 cartridges (Waters, Milford, Mass., USA) [6] with slight modification. Plasma samples and all reagents were applied to the Sep-Pak using Syringe Infusion Pump 22 (Model 2400-006, Harvard Apparatus, South Natick, Mass., USA) at a rate of $25 \mathrm{ml} / \mathrm{h}$. Ten samples (eight plasma samples, one pool plasma and one pool plasma containing standard human IAPP-NH${ }_{2}$ ) were extracted simultaneously. The eluate was evaporated and resolved by the radioimmunoassay (RIA) buffer ( $0.1 \mathrm{~mol} / \mathrm{l}$ sodium phosphate buffer, $\mathrm{pH} 7.4$, containing $0.1 \%$ Triton-X, $0.05 \mathrm{~mol} / 1 \mathrm{NaCl}, 0.1 \%$ bovine serum albumin and $0.01 \% \mathrm{NaN}_{3}$ ). The recovery of this extraction was 84.3 to $96.5 \%$ $(92.6 \pm 1.5 \%, n=9)$. The serial dilution curves of the plasma extracts were parallel to a standard curve. HPLC analysis revealed that immunoreactive IAPP in the plasma extracts eluted as a single peak which coincided with synthesized human IAPP-NH $\mathrm{NH}_{2}$.

\section{Assay procedures}

IAPP was measured by RIA [6] using Human Amylin Radioimmunoassay Kits (Peninsula Laboratory, Inc., Belmont, Calif., USA). Synthesized human IAPP-NH $\mathrm{N}_{2}$ [4] was used as an RIA standard instead of the kit standard. Between and within-assay variations were less than $9.6 \%$ and less than $5.8 \%$, respectively. The detection limit of the assay was $2 \mathrm{fmol} / \mathrm{tube}$.

Plasma insulin and C-peptide were measured by RIA using Phadeseph Insulin RIA (Pharmacia Diagnostics, Uppsala, Sweden) and C-peptide RIA (Shionogi, Osaka, Japan), respectively. Plasma glucose was assayed by the glucose oxidase method.

\section{Statistical analysis}

The data are shown as mean \pm SEM. The statistical analysis was carried out by the Student's " $t$ " test, and a $p$ value $<0.05$ was considered significant.

\section{Results}

\section{Fasting plasma IAPP concentration (Table 1)}

In the normal control subjects (non-obese), the plasma IAPP level was $6.4 \pm 0.5 \mathrm{fmol} / \mathrm{ml}(24.9 \pm 2.0 \mathrm{pg} / \mathrm{ml})$ and exhibited no difference between male and female subjects. This concentration was about $1 / 7$ of that of insulin in molar basis. In the non-obese subjects, the fasting IAPP in the patients with IGT or Type 2 diabetes treated without insulin was not significantly different from that of the control subjects, while the fasting IAPP in the patients with Type 1 diabetes or Type 2 diabetes treated with insulin was significantly lower than that in the control subjects. The obese patients with IGT or Type 2 diabetes (treated without insulin) had significantly higher fasting IAPP levels than non-obese control subjects.

Although the level of IAPP in non-obese Type 2 diabetes without insulin therapy was equal to that of the control subjects or those with IGT, insulin or C-peptide levels in this group were significantly $(p<0.05, p<0.01$, respectively) higher than those in the control subjects or patients with IGT, resulting in significantly $(p<0.05)$ lower IAPP/insulin or IAPP/C-peptide molar ratio in this group. The IAPP/insulin or C-peptide molar ratio in the obese Type 2 diabetic group was also low compared to those of the control subjects but not significant. Among the nonobese Type 2 diabetic patients, there was no difference in these ratios between the groups of long duration (more than 10 years) and short duration (less than 3 years) of the disease.

There were no significant differences in fasting insulin/C-peptide molar ratio among the groups.

\section{Plasma IAPP responses during OGTT}

Plasma IAPP responses during OGTT are shown in Figure 1. The peaks of the responses were seen $60 \mathrm{~min}$ after oral glucose load in the normal control subjects but 

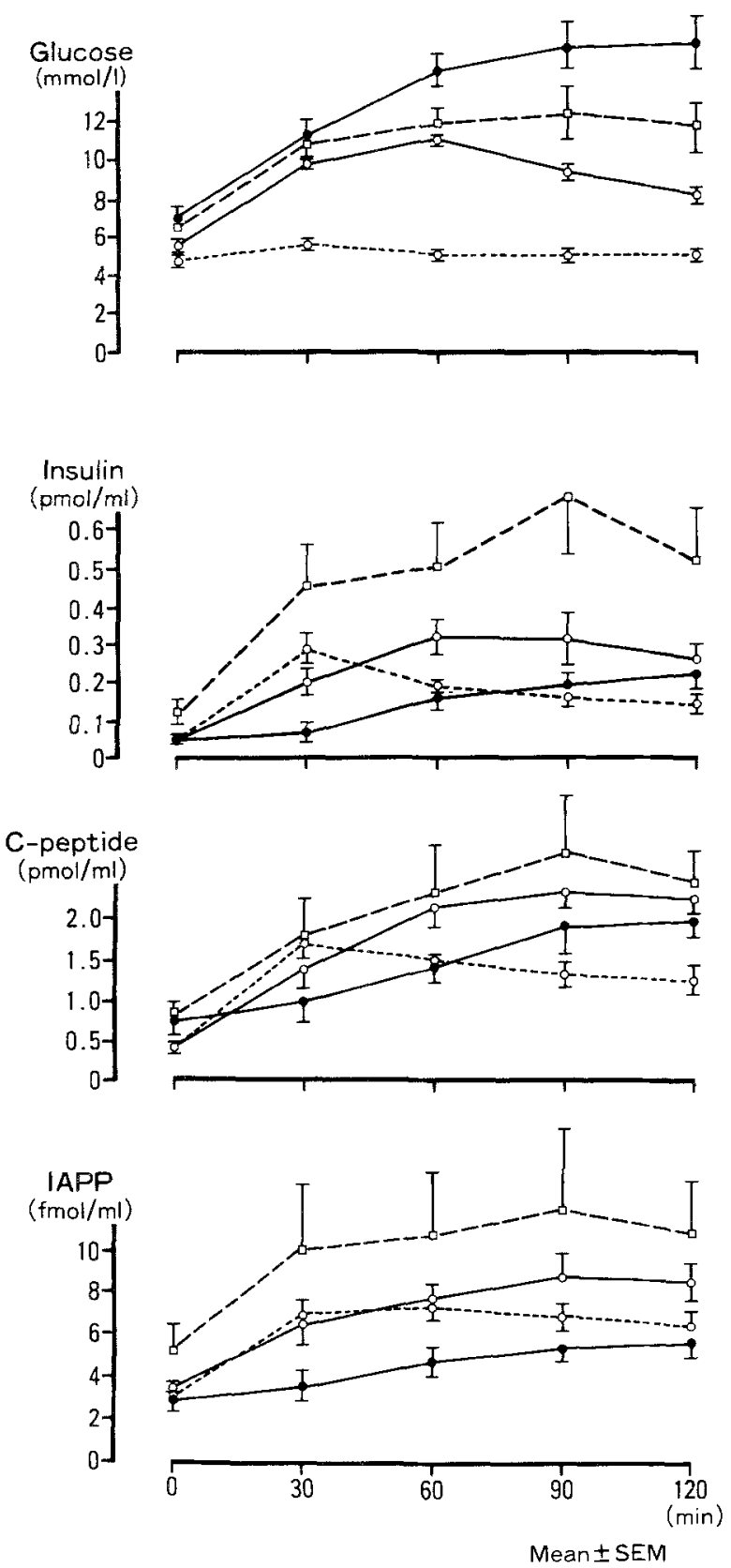

Fig. 1. Plasma glucose, insulin, C-peptide and islet amyloid polypeptide (IAPP) responses during oral glucose tolerance test. Dashed line with open circle: normal control subjects $(n=11)$, solid line with open circle: non-obese patients with impaired glucose tolerance $(n=12)$, solid line with closed circle: non-obese patients with Type 2 diabetes $(n=8)$, broken line with open square: obese patients with impaired glucose tolerance or Type 2 diabetes $(n=12)$

occurred later in the patients with abnormal glucose tolerance or obesity. The magnitude of the IAPP responses increased in the obese patients and decreased in the non-obese Type 2 diabetic patients. These patterns of the IAPP responses were similar to those of insulin or C-peptide.

The areas under the curves above basal of IAPP $\left(A U C_{I A}\right)$, insulin $\left(A U C_{I N}\right)$, C-peptide $\left(A U C_{C P}\right)$ and plasma glucose $\left(\mathrm{AUC}_{\mathrm{PG}}\right)$ during $120 \mathrm{~min}$ of OGTT were calculated and the ratios of $\mathrm{AUC}_{\mathrm{IA}} / \mathrm{AUC}_{\mathrm{CP}}\left(\mathrm{AUC}_{\mathrm{IA} / \mathrm{CP}}\right)$ and $A U C_{\mathrm{NN}} / \mathrm{AUC}_{\mathrm{CP}}\left(\mathrm{AUC}_{\mathrm{IN} / \mathrm{CP}}\right)$ were compared between the non-obese and obese groups with IGT or Type 2 diabetes whose peaks of IAPP, insulin or C-peptide occurred at almost the same time (Table 1). The AUC $\mathrm{PG}_{\mathrm{PG}}$ in non-obese IGT, obese IGT, non-obese Type 2 diabetes and obese Type 2 diabetes was $3.45 \pm 0.13,3.43 \pm 0.13,5.67 \pm 0.45$, and $6.16 \pm 0.49 \mathrm{mmol} \cdot \mathrm{h} \cdot \mathrm{I}^{-1}$, respectively. In the patients with IGT, the $\mathrm{AUC}_{\mathrm{IN} / \mathrm{CP}}$ in the obese group which was expected to have insulin resistance was significantly $(p<0.05)$ higher than that in the non-obese group. Similar to the $\mathrm{AUC}_{\mathrm{IN} / \mathrm{CP} \text {, the }} \mathrm{AUC}_{\mathrm{IA} / \mathrm{CP}}$ in the obese group was also significantly $(p<0.05)$ higher than that in the non-obese one. These changes, although not statistically significant, could be seen between the obese and non-obese groups of Type 2 diabetes.

\section{Discussion}

The present study demonstrates that fasting plasma IAPP levels in the normal control subjects were $6.4 \pm 0.5 \mathrm{fmol} / \mathrm{ml}$, almost coinciding with the previous findings by others $[6,7]$. The levels in the non-obese patients with IGT or mild Type 2 diabetes did not differ from those seen in the control subjects. We also demonstrated that the fasting IAPP significantly decreased in the patients with Type 2 diabetes treated with insulin, obviously decreased in Type 1 diabetes and increased in the obese patients with IGT or Type 2 diabetes.

Since IAPP is supposed, according to recent studies $[3,7]$, to be a normal islet hormone and to play some role in modulating glucose metabolism, it is very important to clarify the peripheral molar ratio of IAPP/insulin as well as the peripheral concentrations of IAPP. This study revealed that peripheral plasma IAPP/insulin molar ratio in normal control subjects was about $1 / 7$. This ratio and the peripheral concentrations allows us to re-evaluate the previous in vivo or in vitro studies using synthesized IAPP. We previously reported that by using the hyperinsulinaemic euglycaemic glucose clamp study, synthesized IAPP amide causes peripheral insulin resistance in vivo in dogs [4]. However, the peripheral IAPP concentration and IAPP/insulin molar ratio during IAPP infusion in our previous study which caused peripheral insulin resistance were about $18 \mathrm{pmol} / \mathrm{ml}$ and $13 / 1$, respectively, which are 3000 times and 100 times higher than human control levels, respectively. The insulin antagonistic effects of the infused IAPP was thus not a physiological action.

Recently we obtained a finding that rat IAPP amide $\left(10^{-8}\right.$ to $\left.10^{-11} \mathrm{~mol} / \mathrm{l}\right)$ is not extracted from the perfused rat liver (unpublished data). It is supposed, therefore, that a portal IAPP/insulin molar distribution is less than $1 / 14$ taking into account $50 \%$ hepatic insulin extraction and the longer half-life of IAPP in the bloodstream [8]. This small molar ratio of IAPP relative to insulin is compatible with the recent findings using monolayer cultures of neonatal rat pancreata [3].

The fasting IAPP/C-peptide molar ratio decreased in patients with Type 2 diabetes. However, the ratio in IGT subjects was the same level as the control subjects. It has 
been reported that there was no difference in the metabolic clearance rate of biosynthetic human C-peptide between non-diabetic subjects and patients with Type 2 diabetes [9]. Thus, decreased IAPP/C-peptide molar ratio in Type 2 diabetes indicates the decreased basal IAPP secretion relative to C-peptide (insulin) and/or shortened IAPP metabolic clearance rate in Type 2 diabetes. Taking into account an immunohistochemical study by Westermark et al. [10] that very few IAPP-cells were seen despite a strong reaction of the Beta cells with antiserum to insulin in the patients with Type 2 diabetes, our results suggest that basal hypo-secretion of IAPP relative to insulin exists in the patients with Type 2 diabetes.

It is generally accepted that obese patients have insulin resistance. In such patients, delayed metabolic clearance rate of insulin due to insulin resistance causes hyper-response of plasma insulin relative to C-peptide which has no biological activity. In this study, we were unable to compare the AUC between non-diabetic control subjects and patients with IGT or Type 2 diabetes, because patterns of responses in each Beta cell product differ during OGTT. However, patients with both IGT and Type 2 diabetes had delayed insulin, C-peptide and IAPP responses, and the pattern of each response was similar. Among the groups, obese patients had hyperresponse of insulin relative to C-peptide compared to members of the non-obese group. This indicates that insulin resistance exists in obese patients. Similar to the relationship between insulin and C-peptide, obese patients had hyper-response of IAPP relative to C-peptide compared to those in non-obese patients. If IAPP has no biological action(s) like C-peptide, the ratio of AUC of these Beta cell products $\left(A U C_{\mathrm{IA} / \mathrm{CP}}\right)$ in obese patients should be the same as those in non-obese patients. Although the true biological action(s) of IAPP has not yet been elucidated, this result suggests that IAPP may act biologically with insulin to modulate the glucose metabolism.

Acknowledgements. This work was supported by a Grant-in-Aid for Scientific Research (No01480294) from the Ministry of Education, Science and Culture of Japan.

\section{References}

1. Westermark P, Wernstedt C, Wilander E, Hayden DW, O'Brien TD, Johnson KH (1987) Amyloid fibrils in human insulinoma and islets of Langerhans of the diabetic cat are derived from a neuropeptide-like protein also present in normal islet cells. Proc Natl Acad Sci USA 84: 3881-3885

2. Cooper GJS, Willis AC, Clark A, Turner RC, Sim RB, Reid KBM (1987) Purification and characterization of a peptide from amyloid-rich pancreases of type 2 diabetic patients. Proc Natl Acad Sci USA 84: 8628-8632

3. Kahn SE, D'Alessio DA, Schwartz MW, Fujimoto WY, Ensinck JW, Taborsky GJ, Porte D, Jr (1990) Evidence of cosecretion of islet amyloid polypeptide and insulin by $\beta$-cells. Diabetes 39 : 634-638

4. Sowa R, Sanke T, Hirayama J, Tabata H, Furuta H, Nishimura S, Nanjo K (1990) Islet amyloid polypeptide amide causes peripheral insulin resistance in vivo in dogs. Diabetologia 33:118-120

5. Molina JM, Cooper GJS, Leighton B, Olefsky JM (1990) Induction of insulin resistance in vivo by amylin and calcitonin generelated peptide. Diabetes 39: 260-265

6. Butler PC, Chou J, Carter WB, Wang Y-N, Bu B-H, Chang D, Chang J-K, Rizza RA (1990) Effects of meal ingestion on plasma amylin concentration in NIDDM and nondiabetic humans. Diabetes 39: 752-756

7. Mitsukawa T, Takemura J, Asai J, Nakazato M, Kamgawa K, Matsuo H, Matsukura S (1990) Islet amyloid polypeptide response to glucose, insulin, and somatostatin analogue administration. Diabetes 39:639-642

8. Bretherton-Watt D, Gilbey SG, Ghatei MA, Beacham J, Bloom SR (1990) Failure to establish islet amyloid polypeptide (amylin) as a circulating beta cell inhibiting hormone in man. Diabetologia 33: 115-117

9. Asano T, Kanatsuka A, Sakurada M, Makino E, Yamamoto T, Okumura M, Yoshida S, Kajinuma H (1990) Kinetic studies of biosynthetic human C-peptide in normal subjects and non-insulin dependent diabetic patients. J Japan Diab Soc 33: 359-363

10. Westermark P, Wilander E, Westermark GT, Johnson KH (1987) Islet amyloid polypeptide-like immunoreactivity in the islet B cells of Type 2 (non-insulin-dependent) diabetic and nondiabetic individuals. Diabetologia 30: 887-892

Received: 28 September 1990

and in revised form: 18 October 1990

Dr. T. Sanke

The First Department of Medicine

Wakayama University of Medical Science

27 Nanaban-cho

Wakayama 640

Japan 